ISSN 2616-7328 (Online), ISSN 2409-904X (Print)

Kitaêznavčì doslìdžennâ, 2018, No. 1, pp. 58-68

UDC 94(510)

doi: https://doi.org/10.15407/chinesest2018.01.058

\title{
SEMANTICS AND PRAGMATICS OF THE BELT AND ROAD INITIATIVE CONCEPT
}

\section{Kiktenko}

DSc (Philosophy), Senior Fellow

A. Yu. Krymskyi Institute of Oriental Studies, NAS of Ukraine

4, Hrushevskoho Str., Kyiv, 01001, Ukraine

kiktenko@gmail.com

In the article on the basis of linguistic data (etymology of words and hieroglyphics, word-wording and interpretation of words), THE BELT AND ROAD INITIATIVE («一带 一路 (国家级顶层合作倡议)») is studied as an abstract and metaphorical concept. It is determined that China's current initiative transforms the ancient Silk Road into a myth, because it is determined by its exclusive affiliation with the Chinese civilization, which contradicts historical facts. THE BELT AND ROAD INITIATIVE semantically absorbs into itself the ancient and new Silk Road, which in fact is a struggle with Western conception of the past and a return of the Sinocentrism. As a result of the study, it is argued that THE BELT AND ROAD INITIATIVE is a Chinese way of thinking to create a single, protective path that simultaneously mythologizes and globalizes the historic Silk Road to address the modern challenges of China's modernization and globalization.

Keywords: concept, metaphor, China, Silk Road, Belt and Road Initiative

\section{СЕМАНТИКА І ПРАГМАТИКА КОНЦЕПТУ ІНІЦІАТИВА “ОДИН ПОЯС, ОДИН ШЛЯХ”}

\section{B. О. Кіктенко}

7 вересня 2013 року під час державного візиту до Казахстану голова КНР Сі Цзіньпін висунув ідею “Економічного поясу Шовкового шляху” (“丝绸之 路经济带”, “Sīchóu zhī lù jīngjì dài’” для посилення торгово-економічної співпраці Китаю з країнами Центральної Азії та з іншими регіонами Свразії шляхом створення сухопутних транспортних мереж. Через місяць, під час візиту до Індонезії, Сі Цзіньпін закликав до створення "Морського шовкового шляху XXI століття" (“二十一世纪海上丝绸之路”, “Ėrshíȳ̄ shìjì hăishàng sīchóu zhī lù”), спрямованого на розвиток економічних зв'язків Китаю морським шляхом з країнами Південно-Східної Азії, Південної Азії та Африки. 3 часом нова концепція зовнішньої політики й економічної стратегії КНР дістала назву «Державна ініціатива Китаю вищого рівня співпраці “Один пояс, один шлях"» (“一带一路 (国家级顶层合作倡议)”, “Ȳ̄dài yīlù (Guójiā jí dǐngcéng hézuò chàngyi)"), або скорочено “Один пояс, один шлях” (“一带一路”, “Yīdài yīlù”) (рис. 1). Ця ініціатива викликали неабиякий інтерес та жваві дискусії серед експертів у більш глобальному контексті обговорення концепції “китайська мрія” (“中国梦”, “zhōngguó mèng”) - прагнення Китаю до “національного відродження” (“复兴中华”, “Відродження Китаю”) [Кіктенко 2017a; Callahan

(C) 2018 V. Kiktenko; Published by the A. Yu. Krymskyi Institute of Oriental Studies, NAS of Ukraine and the Ukrainian Association of Sinologists on behalf of The Chinese Studies. This is an Open Access article distributed under the terms of the Creative Commons Attribution License (https://creativecommons.org/licenses/by-nc-nd/4.0/). 
2013; 杜德斌 2015]. Сьогодні пошук у Google англійської назви ініціативи "The Belt and Road Initiative" видає приблизно 22500000 посилань на статті та коментарі, а в китайській пошуковій системі Baidu оригінальна назва "一带 一路” зустрічається 14000000 разів.

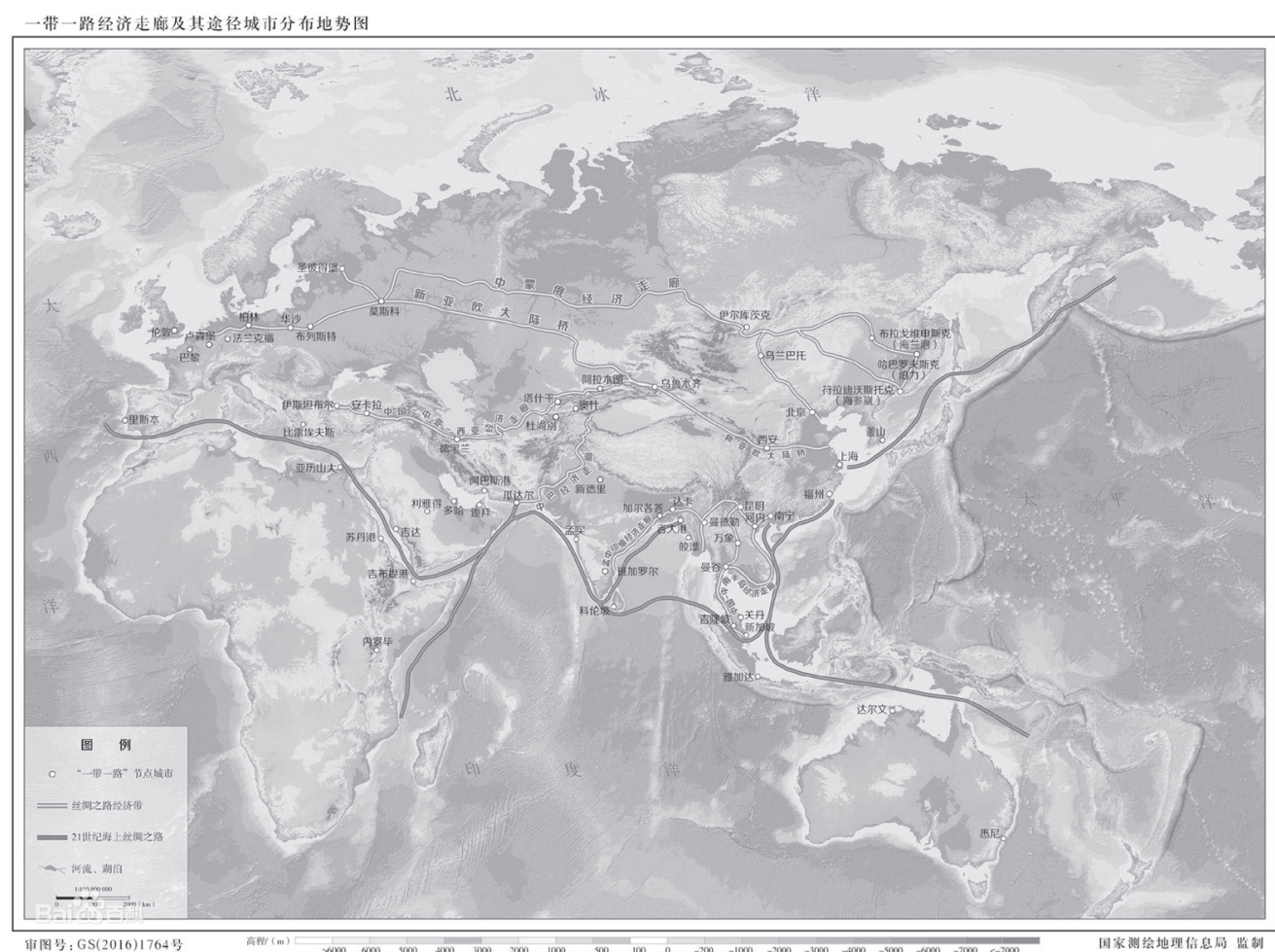

Рис. 1. Карта ініціативи “Один пояс, один шлях"

Однак усі ці загальновідомі дані не прояснюють сам концепт ІНІЦІАТИВА “ОДИН ПОЯС, ОДИН ШЛЯХ”', який у тих чи інших дослідженнях найчастіше іменується як туманний і невизначений. Більш того, на первісному етапі формулювання цього концепту багато китайських вчених у приватних бесідах називали його порожнім поняттям, а не так давно, 10 квітня 2018 року, на Боаоському азіатському форумі сам голова КНР Сі Цзіньпін заявив, що оскільки “Один пояс, один шлях" є новою ініціативою, то абсолютно природним $є$ те, що стосовно неї існують різні думки [习近平... 2018]. Передусім це вказує на понятійну розмитість, бо зміст концепту може змінюватися та значно розширюватися залежно від прагматичних потреб суб'єкта висловлювання. У свою чергу, це не тільки збільшує обсяг та кількість висловлювань, а й відповідно надає більш широкі можливості для прийняття рішень китайською стороною. Все це вказує на необхідність прояснити сам зміст концепту на основі лінгвістичних даних (етимологія слів та ієрогліфів, слововживання та тлумачення слів) з урахуванням можливих мотивів ініціаторів проекту.

\section{1. ІНЦЦАТИВА “ОДИН ПОЯС, ОДИН ШЛЯХ”: етимологія концепту та особливості перекладу}

Керівник Стратегічного дослідницького центру “Один пояс, один шлях" Академії наук КНР професор Лю Вейдун прямо стверджує, що неправильно

\footnotetext{
${ }^{1}$ Великими літерами в тексті позначаються концепти.
} 
розуміти “Один пояс, один шлях" як чітко визначені, фіксовані та заздалегідь позначені на географічних картах суходільні та морські маршрути. Замість цього він пропонує розглядати цю ініціативу як “абстрактну та метафоричну концепцію” (“抽象性和隐喻性的概念”, “chōuxiàng xìng hé yǐnyù xìng de gàiniàn”), у якій відбувається відновлення культурного змісту старого Шовкового шляху - символу культурного обміну та історичних торговельних відносин Китаю зі світом. Мета цього процесу полягає у створенні платформи для регіонального та глобального економічного співробітництва, і тому не існує стійких, конкретних поясу та шляху. Китайський вчений вважає, що ОДИН ПОЯС, ОДИН ШЛЯХ - це культурна метафора, яка визначає два проекти 3 експансивними географічними можливостями на суші та на морі для активізації глобальних економічних обмінів та взаємодій. У цілому Лю Вейдун стверджує, що “Один пояс, один шлях" - це креативний та відкритий проект [ 刘卫东 2016]. Цікаво, що в роботах китайських вчених, присвячених ініціативі “Один пояс, один шлях", фактично нічого не можна знайти про етимологію самого концепту.

11 травня 2015 року на офіційному порталі ініціативи “Один пояс, один шлях" було розміщено програмний документ «Спільне будівництво “Одного поясу, одного шляху”: концепція, практика та внесок Китаю» ( 《共建“一带一 路”: 理念实践与中国的贡献》, “Yīdài yīlù": lǐniàn shíjiàn yǔ zhōngguó de gòngxiàn”) [ 《共建“一带一路”... 》]. Цей документ цікавий не тільки тому, що в ньому наводиться офіційна позиція Пекіну, а й тому, що він подається, окрім оригіналу, шістьма мовами (англійська, арабська, іспанська, німецька, російська, французька) - показник пріоритетів у виборі Китаєм головних партнерів по ініціативі та важливий лінгвістичний матеріал для аналізу семантики концепту ІНІЦАТИВА “ОДИН ПОЯС, ОДИН ШЛЯХ” не тільки в оригінальному варіанті, а й через його “свідому” передачу в інші культури (рис. 2). Насамперед необхідно відзначити, що хоча в китайському тексті 42 рази використовується назва “丝绸之路” (“Шовковий шлях"), проте в самій назві ініціативи як в оригіналі, так і в будь-якому перекладі на іншу мову (окрім німецької) цей термін не використовується, і це не випадково.

Рис. 2. Офіційна назва ініціативи “Один пояс, один шлях” сьома мовами

\begin{tabular}{|c|c|c|}
\hline Мова & Назва & Переклад \\
\hline Англійська & $\begin{array}{l}\text { Building the Belt and Road: } \\
\text { Concept, Practice and China's } \\
\text { Contribution }\end{array}$ & $\begin{array}{l}\text { Будівництво Поясу та Шляху: концеп- } \\
\text { ція, практика та внесок Китаю }\end{array}$ \\
\hline Арабська & 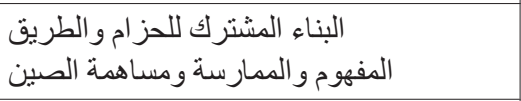 & $\begin{array}{l}\text { Спільне будівництво Поясу та Шляху: } \\
\text { концепція, практика та внесок Китаю }\end{array}$ \\
\hline Іспанська & $\begin{array}{l}\text { Construcción conjunta de "la } \\
\text { Franja y la Ruta": Concepto, } \\
\text { práctica y contribución de China }\end{array}$ & $\begin{array}{l}\text { Спільне будівництво “Смуги та Шля- } \\
\text { ху": концепція, практика та внесок Ки- } \\
\text { таю }\end{array}$ \\
\hline Китайська & $\begin{array}{l}\text { 《共建“一带一路”: 理念 实践与 } \\
\text { 中国的贡献》 }\end{array}$ & $\begin{array}{l}\text { Спільне будівництво “Одного поясу, } \\
\text { одного шляху”: концепція, практика та } \\
\text { внесок Китаю }\end{array}$ \\
\hline Німецька & $\begin{array}{l}\text { Die "Neue Seidenstraßeninitia- } \\
\text { tive": Konzept, Praxis und Chinas } \\
\text { Beitrag }\end{array}$ & $\begin{array}{l}\text { Ініціатива “Новий Шовковий шлях": } \\
\text { концепція, практика та внесок Китаю }\end{array}$ \\
\hline
\end{tabular}




\begin{tabular}{|l|l|l|}
\hline Російська & $\begin{array}{l}\text { Совместное строительство “Од- } \\
\text { ного пояса, одного пути": идея, } \\
\text { практика и вклад Китая }\end{array}$ & $\begin{array}{l}\text { Спільне будівництво “Одного поясу, } \\
\text { одного шляху": ідея, практика і внесок } \\
\text { Китаю }\end{array}$ \\
\hline Французька & $\begin{array}{l}\text { Construction conjointe de “la Cein- } \\
\text { ture et la Route": conception, pra- } \\
\text { tique et contribution chinoise }\end{array}$ & $\begin{array}{l}\text { Спільне будівництво “Поясу та Шля- } \\
\text { хуонцепція, практика та внесок Ки- } \\
\text { таю }\end{array}$ \\
\hline
\end{tabular}

У 1877 році саме німецький вчений Фердинанд фон Ріхтгофен запропонував терміни "Seidenstraße" i "Seidenstraßen" (“Шовковий шлях", або “Шовковий маршрут”) для назви караванної дороги, що зв'язувала Східну Азію із Середземномор'ям у давнину і в середні віки (рис. 3). Цим маршрутом протягом століть переміщувались не тільки різні товари, а й релігії - буддизм, християнство та іслам. Проте ці культурні та комерційні обміни увесь цей тривалий час не були якимось політично обгрунтованим проектом будь-якої країни, поки це не відбулось у концепції “Шовкового шляху” німецького географа. Тобто первісно виникла ідея створення безперервного торговельного коридору, який іде з Свропи до Азії, проте сучасна китайська ініціатива - це, навпаки, рух з Азії до Свропи. Фердинанд фон Ріхтгофен пропагував будівництво залізниці з Свропи до Східного Китаю, де в Німеччини в той час були свої інтереси, проте він помер у 1905 році й проект залишився проектом [Waugh 2007]. Події, які розгорнулися потім, і зокрема Перша світова війна, взагалі унеможливили реалізацію побудови нового Шовкового шляху, і в кінцевому підсумку ідея була відкинута. Проте більш важливо, що Фердинанд фон Ріхтгофен не просто запропонував назву, а й закріпив ідею того, що Китай був ініціатором та ключовим елементом історичного Шовкового шляху. Насправді цим шляхом ішли різноманітні товари й сам Китай був зацікавлений в отриманні золота, коней, пігментів, дорогоцінних каменів 3 різних країн.

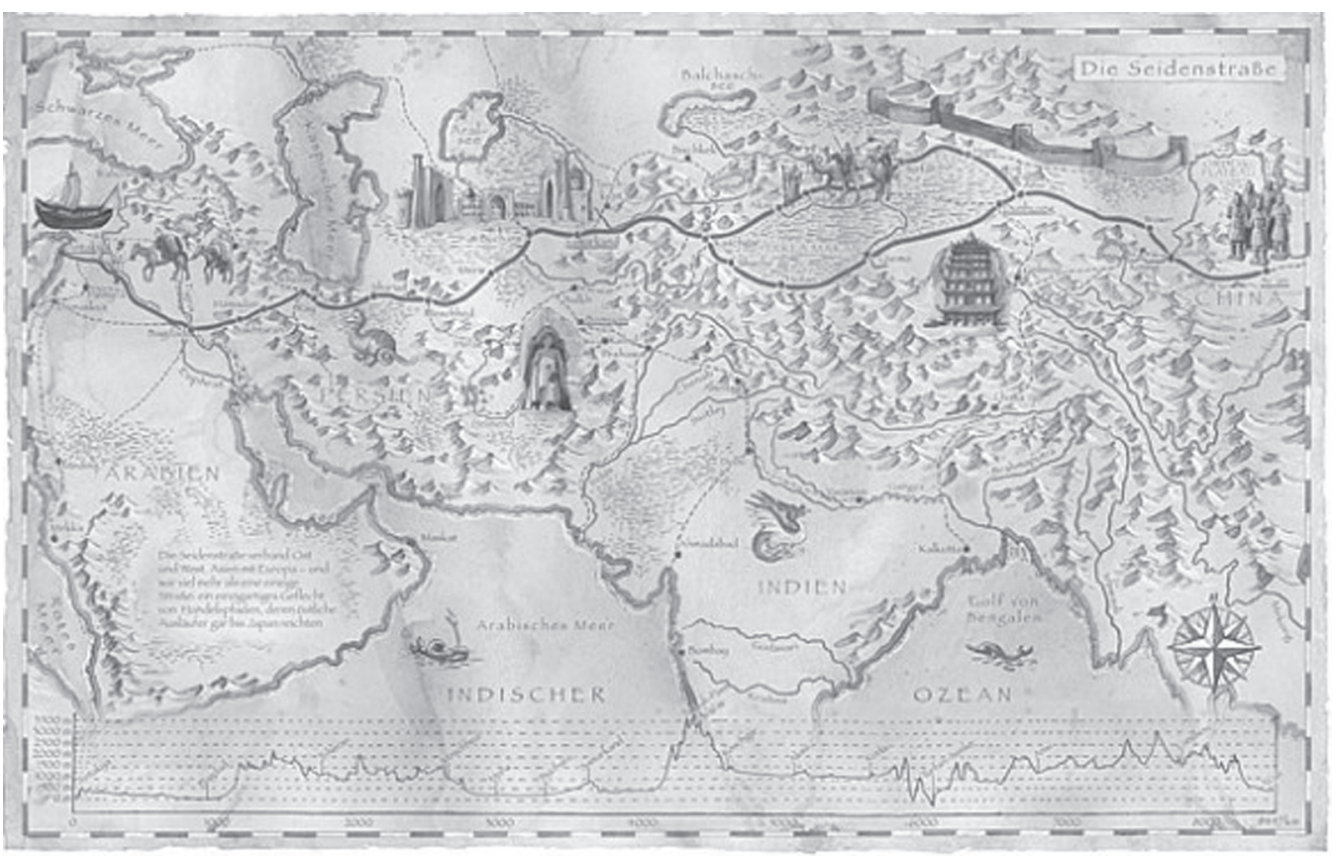

Рис. 3. Карта Шовкового шляху Фердинанда фон Ріхтхофена (1877 р.)

Отже, всі сучасні назви Шовкового шляху будь-якою мовою походять від німецького оригіналу, і довгий час цей термін сприймався в Китаї як чужорідний, 
а за часів холодної війни, радянсько-китайського розколу та стагнації китайської економіки взагалі не могла відродитися навіть ідея створення трансконтинентального маршруту. Досягнення ж Китаєм рівня другої економіки світу відродило можливості розширення впливу країни, але вже не в регіоні, а на глобальному рівні, що, відповідно, передбачає відтворення старих та будівництво нових торгових шляхів з метою підключення Китаю до майже всіх ринків світу. Отже, глобальність ІНІЦІАТИВИ "ОДИН ПОЯС, ОДИН ШЛЯХ" суттєво відрізняється за масштабом від старих маршрутів, які поєднували Китай часів династії Хань (206 р. до н. е. -220 р. н. е.) і Тан (618-906 pp.) з Центральною Азією. Наука на сьогодні не володіє точними даними щодо обсягів торгівлі суходолом у ті часи на цьому маршруті, але можна точно сказати, що вона була невеликою й фактично локальною (система локальних торгівель). Насамперед цей шлях використовувався для вивезення шовку з Китаю, з чим i була пов'язана запропонована Фердинандом фон Ріхтгофеном назва. Більш важливим $€$ те, що локальна торгівля викликала велике культурне змішування, бо цими фрагментарними шляхами поширювалися філософські думки, наукові ідеї, релігії, художні стилі та писемність. Тому збереження оригінальної назви (Шовковий шлях) у перекладі на німецьку мову ІНІЦІАТИВИ “ОДИН ПОЯС, ОДИН ШЛЯХ” можна вважати даниною поваги з боку китайської сторони країні, представник якої створив необхідні смислові передумови для безпосереднього здійснення цього проекту, що, крім того, надає особливого статусу Німеччині на сучасному етапі в геоекономічній ініціативі КНР. До того ж привертає увагу те, що в інших варіантах перекладу будівництво “Одного поясу, одного шляху”, окрім оригіналу, називається спільним (共建, gòng jiàn) в арабському, російському, іспанському та французькому перекладі. Сniльність не пропонується в англійському та німецькому перекладах, проте це, скоріш за все, вказує не на небажання спільних дій, а на особливу роль Великої Британії та Німеччини в цій ініціативі, що справді підтверджується конкретними прикладами у двосторонніх відносинах Китаю з цими країнамиㄹ․

На Заході використання терміна “Шовковий шлях” (або “Шовкові шляхи”) поширилось у період Другої світової війни, але більш широке його вживання розпочалося в 1960-х роках, насамперед у популярних творах ${ }^{3}$, i поступово він потрапив до наукових праць. За визначенням С. Вітфілд, уперше "Шовковий шлях” китайською мовою (“丝绸之路”, “Sīchóu zhī lù”) зустрічається в каталозі 1972 року Сіньцзянського музею в Урумчі, але до 1980-х років у Китаї цей термін був трюїзмом і визначення "Шовкового шляху” не мало нічого спільного із сучасним глобальним розумінням "Одного поясу, одного шляху" [Whitfield 2007, 202]. За останні кілька десятиліть на Заході термін "Шовковий шлях" використовувався в документальних та художніх фільмах, в інтернет-просторі та популярних книжках, у дипломатії та туристичній сфері [Thorsten 2005, 301]. У середині 2000-х років термін “Шовковий шлях" почали вживати в американських стратегіях для трансформації постталібського Афганістану торговельними та дипломатичними заходами, що мало в результаті привести до гегемонії США в Центральній Азії [Laruelle 2015]. У 2011 році тодішній державний секретар США Хілларі Клінтон офіційно заявила про

\footnotetext{
${ }^{2}$ Докладно про особливості становища цих країн у геоекономіці Китаю див.: [Кіктенко 2017b].

${ }^{3}$ Наприклад, Luis Boulnois “The Silk Road".
} 
американську ініціативу Нового шовкового шляху, згідно з якою передбачалась інтеграція Афганістану в регіональну енергетику та торговельні ринки, зосереджені на зв'язках із Південною та Центральною Азією, але без згадки про Китай. Проте китайський “Один пояс, один шлях” дуже швидко фактично зруйнував цю американську пропозицію.

Стародавній та середньовічний Шовковий шлях виник внаслідок торгівлі, яка здійснювалася багатьма народами на європейсько-азіатському просторі, $\mathrm{i}$ тому не може вважатися китайським ані за походженням, ані за функціонуванням. Сьогоднішня ініціатива Китаю перетворює Шовковий шлях на міф, бо визначається його виключна належність саме до китайської цивілізації, що суперечить історичним фактам. ІНІЦІАТИВА “ОДИН ПОЯС, ОДИН ШЛЯХ” семантично поглинає в собі старий і новий Шовковий шлях, зберігаючи тільки історичну символіку. Саму ж ініціативу можна трактувати дуже широко від торгівлі, інвестицій, науки і аж до діалогу цивілізацій та вдосконалення глобального управління. Крім того, відмова від назви “Шовковий шлях" шляхом його семантичного поглинання в скороченій назві “ОДИН ПОЯС, ОДИН ШЛЯХ" - це боротьба із західним осмисленням минулого і повернення до синоцентричної моделі сприйняття світу. У сучасному китайському варіанті відродження/створення “Шовкового шляху” поєднуються торгівля та культурний обмін на давньому маршруті, що є романтизацією історичного торгового шляху. Фактично ж ІНІЦАТИВА “ОДИН ПОЯС, ОДИН ШЛЯХ” $є$ продовженням останнього в часі розширення Китаю за часів панування маньчжурської династії Цин (1644-1911) [Perdue 2010], проте сьогодні це здійснюється зовсім іншими методами для досягнення глобального статусу країни в сучасному світі.

\section{2. Аналіз структурних елементів концепту ІНІЦІАТИВА “ОДИН ПОЯС, ОДИН ШЛЯХ"}

2.1. ІНІЦАТИВА (“倡议”). Лексичне значення “倡议”, “chàngy’” - це “ініціатива”, “проявляти ініціативу”. У 2015 році Національна комісія з розвитку і реформ КНР, Міністерство закордонних справ КНР та Міністерство комерції КНР спільним рішенням рекомендували перекладати слово “倡议” тільки як "initiative" в однині і не використовувати такі слова, як "strategy", "project", "program", "agenda". Як можливий варіант допускався переклад "The land and maritime Silk Road initiative” [《共建“一带一路”... 2017 》]. Такі обмеження, скоріш за все, були пов'язані з бажанням довести відкритість цієї китайської пропозиції до співпраці, яка, на відміну від “стратегії”, “проекту”, “програми” i "плану”, не є завершеним задумом і, відповідно, не містить у собі агресії. Тобто це семантичне розходження між “ініціативою” і “стратегією” чітко вказує на центральне завдання відкритої системи "Поясу і шляху". Цікаво, що спочатку для роз'яснення ІНІЦАТИВИ “ОДИН ПОЯС, ОДИН ШЛЯХ” китайською стороною використовувались такі поняття, як "економічна стратегія” (“经济战略”, “jīngjì zhànlüè”), “стратегічне бачення” (“战略构想”, “zhânlüè gòuxiăng”) та “форум” (“高峰论坛”, “gàofēng lùntán”). Привертають на себе увагу мілітаристські обертони перших двох визначень, у яких використовується слово “стратегія” (战略, zhânlüè: “війна” 战, zhânlüè+ “план”). Проте ця спроба політичного впливу на формування мовного середовища виявилася малоуспішною, бо в англомовній літературі ІНІЦАТИВА “ОДИН ПОЯС, ОДИН ШЛЯХ", як і раніше, розуміється як "project", "strategy" або навіть 
"grand strategy". Втім, важливо ще раз наголосити на китайському розумінні “ОДНОГО ПОЯСУ, ОДНОГО ШЛЯХУ” - це “ініціатива".

2.2. ОДИН (“一”). Лексичне значення “一”, “ур्1” - це “бути єдиним, цілим” та філософське поняття "один”, "одне [єдине], [нерозчленована, неатрибутивна] єдність”, “первісне”, “все”. Тобто в цьому випадку мова йде не про кількість (число), а про стан світу (космологічний процес). Так, легендарний засновник даосизму Лао-цзи використовує поняття “-”” для позначення шляху (“道”, “dào”) - принципу всіх речей у Всесвіті: “道生 一, 一生二”, “Дао народжує одне [нерозчленована єдність], одне народжує два [роздвоєння]” (“Дао де цін”, чжан 42) [Древнекитайская философия 1972, 128]. Це ж поняття використовує для позначення речей інший представник давнього даосизму, Чжуан-цзи, коли розмірковує про рівність речей і стверджує, що для речей немає ані створення, ані руйнування, тому що все знову стає єдиним “一” (“Чжуан-цзи”, розділ "Про рівність речей”) [Древнекитайская философия 1972, 252]. Видатний представник легізму Хань Фей твердить, що шлях “道” не має пари й тому він називається єдиним “一” (“Хань Фей-цзи”, розділ 8) [Древнекитайская философия 1973, 226]. Отже, “一”, “уї” передається метафорою ШЛЯХУ, який розуміється як увесь ВСЕСВIT (ШЛЯХ-ВСЕСВIТ). Далі розглянемо, як це поняття використовується сьогодні на прагматичному рівні.

Голова КНР Сі Цзіньпін стверджує, що ІНІЦАТИВА "ОДИН ПОЯС, ОДИН ШЛЯХ” буде повною мірою спиратися на наявні двосторонні і багатосторонні механізми відповідних країн, застосовувати сучасні ефективні платформи регіонального співробітництва, використовувати історичний символ ІНІЦІАТИВИ “ОДИН ПОЯС, ОДИН ШЛЯХ”, щоб запозичувати досвід стародавнього Шовкового шляху (“古代丝绸之路”, “gǔdài sīchóu zhī lù”) i продовжувати мирний розвиток Китаю. Все це буде спрямовано на розвиток економічних партнерських відносин з країнами "Поясу і шляху” для побудови спільності (“共同体”, “gòngtóngtǐ”) інтересів, долі і відповідальності за політичну взаємну довіру, економічну та культурну інтеграцію. У вже згаданому виступі 29 березня 2015 року на щорічній конференції Боаоського азіатського форуму голова КНР Сі Цзіньпін заявив про те, що Фонд Шовкового шляху та Азіатський банк інфраструктурних інвестицій сприятимуть “економічній зв'язності та індустріалізації нового типу в Азіатсько-Тихоокеанському регіоні, i, таким чином, це буде сприяти загальному (курсив мій. - В. К.) розвитку усіх країн, а також спільному (курсив мій. $-B . K$.) використанню народами плодів розвитку” [习近平... 2018]. Ось ця семантика єдиного вказує на зв'язок ІНІЦІАТИВИ “ОДИН ПОЯС, ОДИН ШЛЯХ” зі старим концептом ПІДНЕБЕСНА (“天下”, “tiānxià”), який має і сучасний варіант - СПІВТОВАРИСТВО ЄДИНОЇ ДОЛІ (“命运共同体”, “Mìngyùn gòngtóngtî”). Тобто все це є прикладами розгорнутого в конкретних висловлюваннях значення "єдиного" (“一”, “у르). Показово, що для характеристики “ОДНОГО ПОЯСУ, ОДНОГО ШЛЯХУ" як багатосторонньої ініціативи використовується метафора СИМФОНІЯ (交响乐, jiāoxiăngyuè) [任彦 2015]. Ця сама ідея єдиного світу реалізується і в повному написанні назви - "Економічний пояс Шовкового шляху" та "Морський шовковий шлях XXI століття",- бо тут поєднуються ЗЕМЛЯ та ВОДА, тобто вся ПІДНЕБЕСНА.

2.3. ПОЯС (“带”). Лексичне значення “带”, “dài” - “пояс", “зона”; “смуга" (території); "район”, “ділянка”, але важливо, що основне значення - це "коло”, “те, що оперізує”. До того ж “带” є новим терміном і не входить у назву 
“Шовковий шлях” (“丝绸之路”, “sīchóu zhī lù”). Тобто ось це привнесення оперізування суттєво змінює первісну назву, бо додає особливий спосіб створення шляху. Ще “带” може вказувати на ключові економічні зони та коридори ІНІЦІАТИВИ “ОДИН ПОЯС, ОДИН ШЛЯХ”. Крім того, у популярному дискурсі “带” також трактується як “приведення когось або чогось разом” виявлення єдиного (“一”), - тому, відповідно, й “один пояс" (“一带”) [Sidaway 2017, 600-601].

2.4. ШЛЯХ (“路”). Наступний елемент “路”, “lù” - це “дорога”, “вулиця”; “шлях”, “маршрут”; “життєвий (творчий) шлях”; “спосіб мислення”; застаріле значення “обплутувати”, “обв’язувати”. Цікаво, що “路”, окрім основного словарного значення “дорога", також близьке до “той, що оперізує”, так само як і “带”. Використання двох різних ієрогліфів, які містять у собі оперізування, вказує на глибинне значення всього концепту ІНІЦІАТИВА “ОДИН ПОЯС, ОДИН ШЛЯХ”, бо “пояс" і “шлях" - це те, що оперізує, пов'язує, обв'язує -

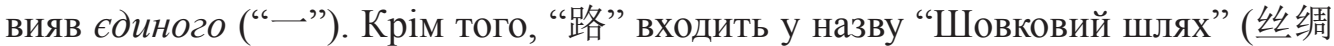
之路, sīchóu zhī lù) i, таким чином, створює історичний зв’язок (символ) зі старим караванним шляхом. Ще “一路” (“один шлях”) має альтернативне значення - “мета подорожі”, що, відповідно, додає цілеспрямованості всій назві [Sidaway 2017, 600-601].

Отже, вираз “ОДИН ПОЯС, ОДИН ШЛЯХ” (“一带一路”) складається 3 двох семантично близьких елементів (“一带” та “一路”), а також у ньому двічі вживається ієрогліф “一” та близькі за значенням ієрогліфи “带” i “路”), що створює очевидний плеоназм, який є характерною рисою китайського, передусім художнього, тексту. Сама структура назви має стандартну класичну форму ідіоми, що складається з чотирьох ієрогліфів (四字成语, si zi chengyu) із внутрішнім паралелізмом ${ }^{4}$. Якщо ж врахувати, що “一”- це теж шлях, то перед нами чотири ієрогліфи, які мають те чи інше значення дороги. Таким чином, ці ієрогліфи зливаються в один знак, в одну лінію, в одну дорогу. Це спосіб мислення “路”, яке космологічно (“一”) створює новий варіант Піднебесної (“天下”) шляхом оперізування світу (“带”)5. Взагалі “一带一路” можна вважати не назвою, а висловом у дусі чань-буддизму, що зосереджений на одному значенні та має потужний психоемоційний вплив. Таким чином, IHIЦІАТИВА “ОДИН ПОЯС, ОДИН ШЛЯХ” (“一带一路 (国家级 顶层合作倡 议)”, “Yīdài yīlù (Guójiā jí dǐngcéng hézuò chàngyì)”) - це китайський спосіб мислення зі створення єдиного, оперізувального шляху, що одночасно міфологізує і глобалізує історичний Шовковий шлях для вирішення сучасних завдань модернізації та глобалізації Китаю.

\section{ЛІТЕРАТУРА}

Древнекитайская философия. Собрание текстов в двух томах. Т. I. Москва, 1972.

Древнекитайская философия. Собрание текстов в двух томах. Т. II. Москва, 1973.

${ }^{4}$ Щиро дякую молодшому науковому співробітнику Інституту сходознавства ім. А. Ю. Кримського НАН України, кандидату філологічних наук Євгенії Гобовій за обговорення цієї статті та висловлені нею окремі критичні зауваження.

5 Для подальших досліджень структурних елементів концепту було б доцільно застосувати корпуси китайської мови, які дають багато прикладів конкретного використання. 
Кіктенко В. О. Китай у сучасному світі: мирне піднесення, відродження нації та "м'яка сила" // Китай очима Азії. Київ, $2017 a$.

Кіктенко В. О. Геоекономічне зростання Китаю у сучасному світі. Стенограма наукової доповіді на засіданні Президії НАН України 22 лютого 2017 року // Вісник Національної академії наук України, 2017b, № 4.

Callahan $W$. China dreams: 20 visions of the future. New York, 2013.

Laruelle M. The U.S. Silk Road: Geopolitical imaginary or the repackaging of strategic interests? // Eurasian Geography and Economics, 2015, Vol. 56, No. 4, pp. 360-75.

Perdue P. C. China Marches West: The Qing Conquest of Central Eurasia. Cambridge, 2010.

Thorsten M. Silk Road nostalgia and imagined global community // Comparative American Studies: An International Journal, 2005, Vol. 3, No. 3.

Sidaway J. D., Woon Chih Yuan. Chinese Narratives on "One Belt, One Road" (一带一路) in Geopolitical and Imperial Contexts // The Professional Geographer, 2017, Volume 69, Issue 4.

Waugh D. C. Richthofen's "Silk Roads": Toward the archaeology of a concept // The Silk Road, 2007, Vol. 5, No 1.

Whitfield S. Was there a Silk Road? // Asian Medicine, 2007, Vol. 3, No. 2.

杜德斌，马亚华。“一带一路”: 中华民族复兴的地缘大战略 // 地理研究, 2015, Vol. 34, No. 6.

《共建“一带一路”: 理念 实践与中国的贡献》 (七语言版本) // 中国一带

一路网，2017年5月.- https://www.yidaiyilu.gov.cn/zchj/qwfb/12658.htm

刘卫东。一带一路战略的认识误区 // 国家行政学院学报, 2016, No1, 页 $3-6$ 。

任彦。“一带一路”是交响乐，不是独奏曲 // 人民网，2015年 03 月 18 日 18 。http://world.people.com.cn/n/2015/0318/c1002-26714292.html

习近平出席博鳌亚洲论坛年会开幕式并发表主旨演讲 // 新华网 2018, 年 4月10日。- http://www.xinhuanet.com/fortune/boao2018kms/index.htm

\section{REFERENCES}

Drevnekitayskaya filosofiya. Sobraniye tekstov $v$ dvukh tomakh (1972), T. I. Mysl', Moskva.

Drevnekitayskaya filosofiya. Sobraniye tekstov $v$ dvukh tomakh (1973), T. II. Mysl', Moskva.

Kiktenko V. O. (2017a), «Kytay̆ u suchasnomu sviti: myrne pidnesennya, vidrodzhennya natsii ta "m"yaka syla"», in Kytay ochyma Aziï, Instytut skhodoznavstva im. A. Yu. Kryms"koho NAN Ukraïny, Ukraïns"ka asotsiatsiya kytayeznavtsiv, Kyïv, 2017, ss. 11-99.

Kiktenko V. O. (2017b), "'Heoekonomichne zrostannya Kytayu u suchasnomu sviti. Stenohrama naukovoyi dopovidi na zasidanni Prezydiyi NAN Ukrayiny 22 lyutoho 2017 roku", Visnyk Natsional”noyi akademiyi nauk Ukrayiny, № 4, ss. $42-60$.

Callahan W. (2013), China dreams: 20 visions of the future, Oxford University Press, New York.

Laruelle M. (2015), "The U.S. Silk Road: Geopolitical imaginary or the repackaging of strategic interests?", Eurasian Geography and Economics, Vol. 56, No. 4, pp. 360-75. 
Perdue P. C. (2010), China Marches West: The Qing Conquest of Central Eurasia, Harvard University Press, Belknap Press, Cambridge.

Sidaway J. D., Woon Chih Yuan (2017), «Chinese Narratives on "One Belt, One Road" (一带一路) in Geopolitical and Imperial Contexts», The Professional Geographer, Volume 69, Issue 4, pp. 591-603.

Thorsten M. (2005), "Silk Road nostalgia and imagined global community", Comparative American Studies: An International Journal, Vol. 3, No. 3, pp. 30117.

Waugh D. C. (2007), «Richthofen's "Silk Roads": Toward the archaeology of a concept», The Silk Road, Vol. 5, No1, pp. 1-10.

Whitfield S. (2007), "Was there a Silk Road?", Asian Medicine, Vol. 3, No. 2, pp. 201-13.

Du Debin, Ma Yahua (2015), «"Yidai yilu”: Zhonghua minzu fuxing di diyuan da zhanlüe», Dili yanjiu, Vol. 34, No. 6, pp. 1005-14.

«Gong jian "yidai yilu": linian shijian yu zhongguo de gongxian» (qi yuyan banben) (2017), available at: https://www.yidaiyilu.gov.cn/zchj/qwfb/12658.htm (accessed 16 June 2018).

Liu Weidong (2016), "Yidai yilu zhanlüe de renshi wuqu", Guojia xingzheng xueyuan xuebao, No1, ye 3-6.

Ren Yan (2015), "“Yidai yilu" shi jiaoxiangyue, bushi duzou qu», available at: http://world.people.com.cn/n/2015/0318/c1002-26714292.html (accessed 23 June 2018).

"Xi Jinping chuxi Bo'ao yazhou luntan nian hui kaimu shi bing fabiao zhuzhi yanjiang" (2018), available at: http://www.xinhuanet.com/fortune/boao2018kms/ index.htm (accessed 16 June 2018).

\section{СЕМАНТИКА I ПРАГМАТИКА КОНЦЕПТУ ІНІЦІАТИВА “ОДИН ПОЯС, ОДИН ШЛЯХ”}

В. О. Кіктенко

У статті на основі лінгвістичних даних (етимологія слів та ієрогліфів, слововживання та тлумачення слів) досліджується ІНІЦАТИВА "ОДИН ПОЯС, ОДИН ШЛЯХ” (“一带一路 (国家级 顶层合作倡议)”) як абстрактна та метафорична концепція. Визначено, що сьогоднішня ініціатива Китаю перетворює давній Шовковий шлях на міф, бо визначається його виключна належність саме до китайської цивілізації, що суперечить історичним фактам. ІНІЦАТИВА “ОДИН ПОЯС, ОДИН ШЛЯХ” семантично поглинає в собі старий і новий Шовкові шляхи, що фактично є боротьбою із західним осмисленням минулого і поверненням до синоцентричної моделі сприйняття світу. У результаті проведеного дослідження стверджується, що ІНІЦІАТИВА “ОДИН ПОЯС, ОДИН ШЛЯХ" - це китайський спосіб мислення зі створення єдиного, оперізувального шляху, що одночасно міфологізує і глобалізує історичний Шовковий шлях для вирішення сучасних завдань модернізації та глобалізації Китаю.

Ключові слова: концепт, метафора, Китай, Шовковий шлях, “Один пояс, один шлях", ініціатива

\section{СЕМАНТИКА И ПРАГМАТИКА КОНЦЕПТА ИНИЦИАТИВА “ОДИН ПОЯС, ОДИН ПУТЬ”}

B. А. Киктенко

В статье на основе лингвистических данных (этимология слов и иероглифов, словоупотребление и толкование слов) исследуется ИНИЦИАТИВА "ОДИН ПОЯС, ОДИН ПУТЬ” (“一带一路 (国家级顶层合作倡议)”) как абстрактная и метафорическая концепция. Определено, что сегодняшняя инициатива Китая превращает старый 
Шелковый путь в миф, так как определяется его исключительная принадлежность именно к китайской цивилизации, что противоречит историческим фактам. Инициатива “ОДИН ПОЯС, ОДИН ПУТЬ” семантически поглощает в себе старый и новый Шелковые пути, фактически являясь борьбой с западным осмыслением прошлого и возвращением к синоцентричной модели восприятия мира. В результате проведенного исследования утверждается, что ИНИЦИАТИВА “ОДИН ПОЯС, ОДИН ПУТЬ” это китайский образ мышления по созданию единого, опоясывающего пути, одновременно мифологизирующий и глобализирующий исторический Шелковый путь для решения современных задач модернизации и глобализации Китая.

Ключевые слова: концепт, метафора, Китай, Шелковый путь, “Один пояс, один путь”, инициатива

Стаття надійшла до редакиії 18.04.2018 